\title{
Cough, fever, joint pain and tender nodules: What is your call?
}

$\infty \quad$ See related article page $\mathrm{I} 53$

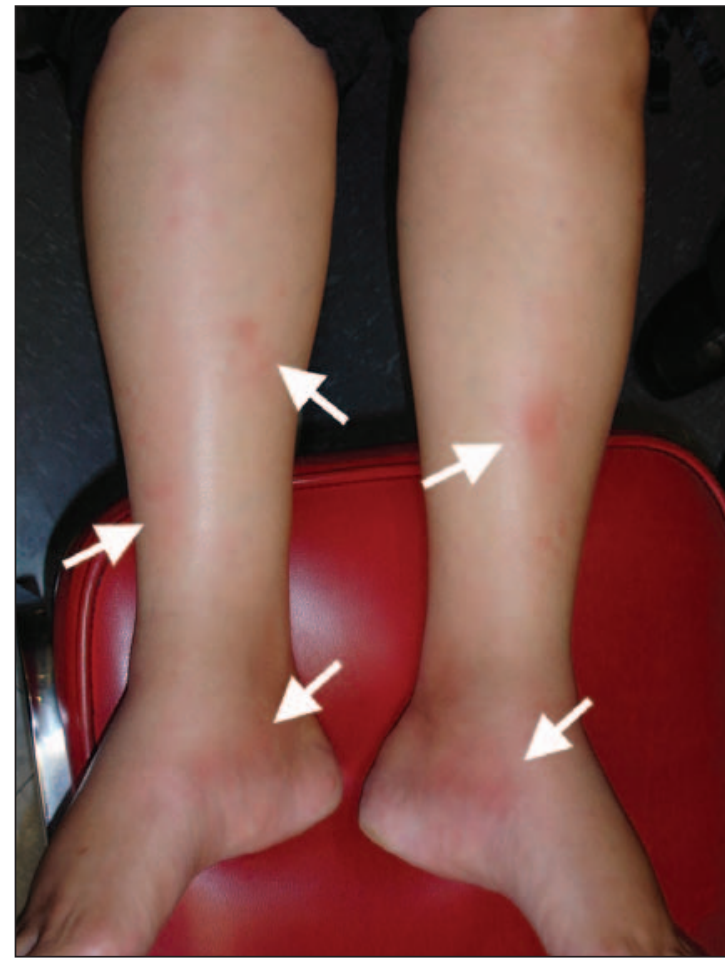

Figure 1: Erythema nodosom at presentation.

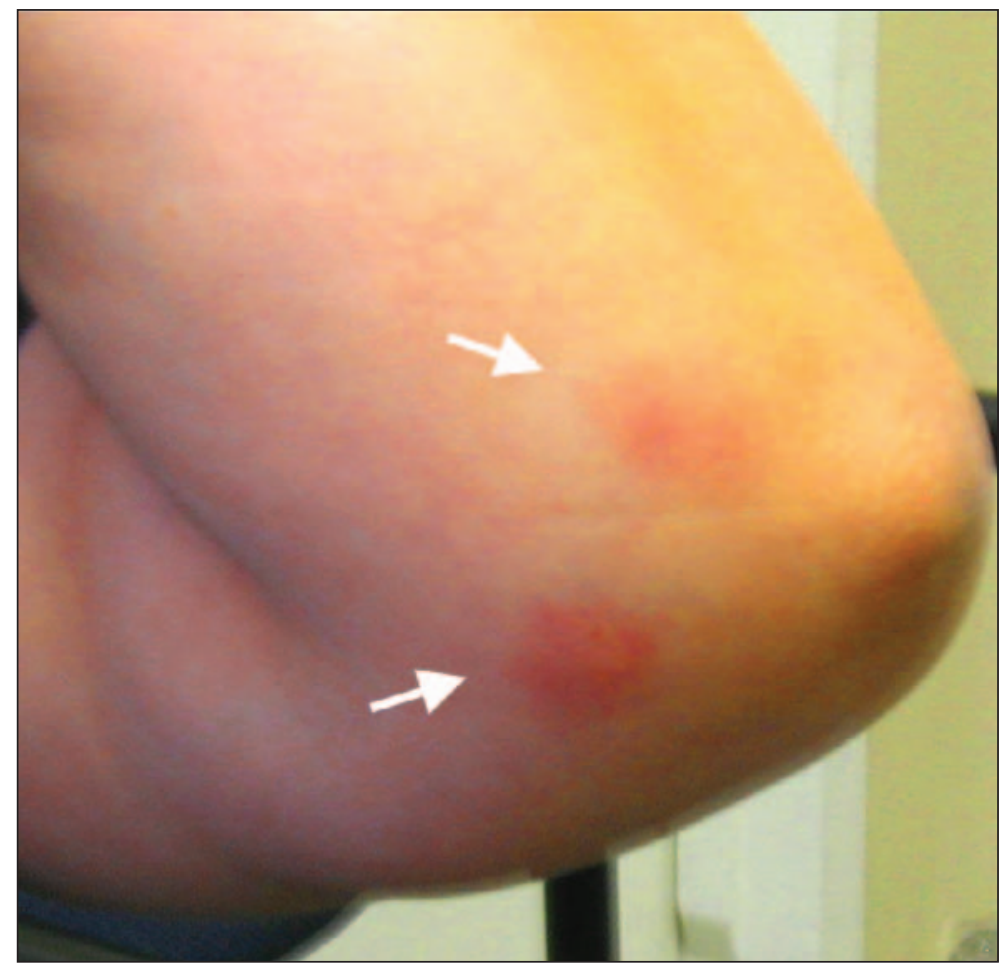

Figure 2: Erythema nodosum around the elbow joint.

\begin{tabular}{|c|c|}
\hline Investigation & Results \\
\hline $\begin{array}{l}\text { Complete blood count with differential, urinalysis, } \\
\text { measurement of creatinine, rheumatoid factor, serum } \\
\text { calcium and angiotensin-converting enzyme levels }\end{array}$ & Within normal limits \\
\hline Erythrocyte sedimentation rate & Elevated at $34 \mathrm{~mm} / \mathrm{h}$ \\
\hline Chest radiography and computed tomography & Bilateral hilar adenopathy \\
\hline Pulmonary function study & Within normal limits \\
\hline $\begin{array}{l}\text { Skin testing for Candida, Streptococcus, Trichophyton } \\
\text { and purified protein derivative antigens }\end{array}$ & Anergy \\
\hline
\end{tabular}

A generally healthy 59-year-old woman presented with a 2- to 3 -month history of dry cough and a I-month history of lowgrade fever, arthralgia and pretibial nodules that were red and painful. Physical examination confirmed a temperature of $38.4^{\circ} \mathrm{C}$, severe bilateral ankle periarthritis and prominent erythema nodosum affecting the lower anterior shins (Figure I) and forearms around the elbows (Figure 2). Relevant investigations are summarized in Table I. Chest imaging revealed bilateral hilar adenopathy.

\section{What is your diagnosis?}

a. Systemic lupus erythematosus

b. Rheumatoid arthritis

c. Sarcoidosis

d. Lymphoma

e. Lyme disease 


\section{Clinical QUiz}

\section{Discussion}

The answer is (c) sarcoidosis. We diagnosed a variant of sarcoidosis known as Löfgren's syndrome based on the patient's history of malaise, low-grade fever, bilateral ankle periarthritis, erythema nodosum and abnormal chest imaging. The patient received a short course of prednisone and colchicine therapy. Her symptoms completely resolved within 6 months and she was still disease-free after 2 years.

Löfgren's syndrome is characterized by a combination of erythema nodosum, fever, hilar adenopathy and migrating polyarthritis mostly affecting the ankle joints (Table 2). The condition tends to be transient, usually remitting after 3-4 months, with or without analgesic-anti-inflammatory therapy.

Sarcoidosis in general: Sarcoidosis is a multi-system disorder of unknown cause with a variable presentation and clinical course. ${ }^{1,2}$ Selected variants of sarcoidosis are outlined in Table 2. Any organ system can be affected, most commonly the lungs ( $90 \%$ of cases) and skin (30\% of cases). Lung involvement ranges from alveolitis and granulomatous infiltration in early sarcoidosis to fibrosis with bronchiolectasis in a later stage of the disease. Hilar and paratracheal lymphadenopathy occur in $90 \%$ of patients. ${ }^{2,3}$

Sarcoidosis is a diagnosis of exclusion based on clinical suspicion of disease and histological confirmation of noncaseating granulomas in at least I organ system after elimination of other causes of granulomatous reactions, such as foreign-body reactions and mycobacterial or fungal infections. The determination of systemic involvement warrants thorough history-taking and physical examination, with an investigation that includes complete blood count, acute phase reactants such as the erythrocyte sedimentation rate or C-reactive protein levels, kidney and liver function tests, thyroid stimulating hormone and chest radiography. Skin anergy is the rule even in benign sarcoidosis. Elevation of the angiotensinconverting enzyme level occurs in about $60 \%$ of patients, and is related to the extent of systemic involvement. This test may be suitable for monitoring disease progression but not for establishing the diagnosis. Ocular symptoms warrant an ophthalmologic exam as part of the initial workup and thereafter with disease exacerbations. Although ocular involvement occurs in about $25 \%$ of patients with sarcoidosis, it is rare in Löfgren's syndrome. The need for further testing follows specific organ involvement. ${ }^{2,3}$
Table 2: Selected variants of sarcoidosis

\begin{tabular}{|c|c|c|c|c|}
\hline $\begin{array}{l}\text { System } \\
\text { involved }\end{array}$ & $\begin{array}{l}\text { Löfgren's } \\
\text { syndrome }\end{array}$ & Lupus pernio & $\begin{array}{l}\text { Heerfordt's } \\
\text { syndrome }\end{array}$ & $\begin{array}{l}\text { Darier-Roussy } \\
\text { syndrome }\end{array}$ \\
\hline Skin & $\begin{array}{l}\text { Erythema } \\
\text { nodosum }\end{array}$ & $\begin{array}{l}\text { Acral } \\
\text { papulonodules } \\
\text { and plaques }\end{array}$ & - & $\begin{array}{l}\text { Subcutaneous } \\
\text { nodules }\end{array}$ \\
\hline Lung & $\begin{array}{l}\text { Hilar } \\
\text { adenopathy }\end{array}$ & $\begin{array}{l}\text { Upper } \\
\text { respiratory } \\
\text { tract } \\
\text { involvement }\end{array}$ & - & - \\
\hline Musculoskeletal & $\begin{array}{l}\text { Ankle } \\
\text { polyarthritis }\end{array}$ & $\begin{array}{l}\text { Lytic bone } \\
\text { lesions }\end{array}$ & - & - \\
\hline Eye & Iritis* & - & Uveitis & - \\
\hline $\begin{array}{l}\text { Central } \\
\text { nervous system }\end{array}$ & - & - & $\begin{array}{l}\text { Cranial nerve } \\
\text { palsy }\end{array}$ & - \\
\hline Other & - & - & $\begin{array}{l}\text { Parotid gland } \\
\text { enlargement }\end{array}$ & - \\
\hline
\end{tabular}

*May or may not be present.
Sarcoidosis involving the skin: Skin involvement may be the first and only manifestation of the disease. ${ }^{3,4}$ The most common cutaneous presentation of sarcoidosis is red-brown papules and plaques distributed symmetrically on the face, lips, neck, upper trunk and extremities. Erythema nodosum, which consists of bilateral tender nodules on the anterior surface of the legs, is common but not specific to sarcoidosis. It is usually predictive of a milder, transient form of the disease that resolves spontaneously.

Treatment is guided by disease severity and progression. Localized cutaneous disease may be treated with topical or intralesional corticosteroid therapy. In cases of generalized or severe cutaneous disease or systemic involvement, prednisone, colchicine, methotrexate, chlorambucil, azathioprine, thalidomide, etanercept and infliximab have been used with success. ${ }^{4}$

\section{Irina Turchin MD \\ Khue Nguyen MDCM \\ Division of Dermatology \\ Henri André Ménard MD \\ Division of Rheumatology \\ McGill University Health Centre \\ Montréal, Que.}

Competing interests: None declared.

\section{REFERENCES}

I. Newman LS, Rose CS, Maier LA. Sarcoidosis. $N$ Engl J Med i997;336:1224-34.

2. Howard A, White CRJr. Non-infectious granuloma. In: Bolognia JL, JorizzoJL, Rapini RP, et al, editors Dermatology. New York: Mosby; 2003. p. 1455-6o.

3. Gawkrodger DJ. Sarcoidosis. In: Burns T, Breathnach S, Cox N, et al, editors. Rook's textbook of der matology. Blackwell Science; 2004. p. 58.I-58.24.

4. White ES. Lynch JP III. Current and emerging strategies for the management of sarcoidosis. EXpert Opin Pharmacother 2007;8:1293-31I.

CMAJ invites contributions to Clinical Quizzes, which allow a focussed imagebased discussion of the diagnosis or management of clinical cases, and are guided by multiple-choice questions. Submit manuscripts online at http://mc .manuscriptcentral.com/cmaj. 